ческих методов исследования микрообъектов и предложено их многоуровневую классификацию. Освещены возможности отдельных оптических методов исследования микрообъектов.

Ключевые слова: метод, методология, оптические методы криминалистических исследований, классификация, систематизация, микроскопия, спектроскопия.

\title{
SCIENTIFIC PARADIGM OF OPTICAL RESEARCH METHODS OF MICROOBJECTS
}

\section{Klymenko N. I., Nenia E. V.}

The research method as a way of scientific cognition is considered, and also the scientific basis of optical research methods of microobjects are presented. The emphasis is placed on the fact that the doctrine of forensic examination methods includes both methodological and practical aspects. The author's definition of the concept "optical methods of criminalistic research» is proposed. Within the frameworks of systematization of optical research methods of microobjects, their division into three main groups is offered: optical microscopy; optical spectroscopy and optical analysis methods based on measurement of light intensity, degree of its polarization and refractivity. The methods which are included in each of mentioned groups are listed. It's grounded the choice of complex classification mechanism which is based on the harmonious combination of the following criteria: physical process underlying the method; questions, raised before the expert; nature of the information on the investigated microobject. Main tasks of outside-and expert studies of microobjects, as well as the methods used to solve them are distinguished. The problems which are solved by using optical methods, and also some of them possibilities for studying characteristics and properties of the most common types of microobjects, are highlighted. A number of new and perspective methods which can be used in the expert research of microobjects is offered. The conclusion, that knowing possibilities of the method and its physical foundations, taking into account the conditions and tasks of the forensic investigation, it's possible to choose the most effective method from all spectrum of existing both optical methods for studying microobjects, and other scientific and technical criminalistic methods and means of research and also analysis of the objects.

Keywords: method, methodology, optical methods of criminalistic research, classification, systematization, microscopy, spectroscopy.

Н. М. Ткаченко, начальник Управління експертного забезпечення правосуддя Департаменту з питань судової роботи та банкрутства Міністерства юстиції України

\section{СУТНІСТЬ ЕКСПЕРТНОГО ЗАБЕЗПЕЧЕННЯ КРИМІНАЛЬНОГО ПРОВАДЖЕННЯ}

Акцентовано увагу на відсутності узгодженої думки стосовно термінології, щзо використовується для позначення діяльності з експертного забезпечення правосуддя в Україні. Розкрито зміст понять «забезпечення», «експертне забезпечення правосуддя», «судово-експертна діяльність» тощо.

(C) Ткаченко Н. М., 2016 
Проаналізовано стан нормативно-правової регламентації поняття «судово-експертна діяльність». Запропоновано розглядати експертне забезпечення кримінального провадження як структурний елемент експертного забезпечення правосуддя. Наведено авторське тлумачення поняття «експертне забезпечення кримінального провадження».

Ключові слова: експертне забезпечення правосуддя, судово-експертна діяльність, кримінальне провадження, судова експертиза.

Кримінальне провадження покликане захищати особу, суспільство та державу від кримінальних правопорушень, охороняти права, свободи й законні інтереси його учасників, забезпечувати швидке, повне та неупереджене розслідування й судовий розгляд для того, щоб кожний, хто вчинив кримінальне правопорушення, був притягнутий до відповідальності в міру своєї вини, жоден невинуватий не був обвинувачений або засуджений, жодна особа не була піддана необгрунтованому процесуальному примусу та щоб до кожного учасника кримінального провадження була застосована належна правова процедура ${ }^{1}$. Для досягнення цього завдання законодавець наділив учасників кримінального провадження певним інструментарієм. Одним із таких інструментів $\epsilon$ проведення судових експертиз. У зв'язку з цим особливої актуальності набуває питання експертного забезпечення кримінального провадження, зокрема стосовно визначення його сутності.

Питання, пов'язані з тлумаченням понять експертного забезпечення правосуддя, судово-експертної діяльності, неодноразово були предметом дослідження в працях таких учених, як О. І. Жеребко, Н. І. Клименко, В. Ю. Мосяженко, О. О. Олійник, І. В. Пиріг, М. Я. Сегай, Р. Л. Сопільник, В. В. Федчишина, В. М. Шерстюк, М. Г. Щербаковський та ін. ${ }^{2}$ Внесок цих

1 Див.: Кримінальний процесуальний кодекс України : Закон України від 13.04.2012 № 4651-VI // Відом. Верхов. Ради України. — 2013. — № 9-10, 11-12, 13. - Ст. 88.

2 Див., напр.: Жеребко О. I. Судово-експертна діяльність: сутність, принципи, організаційні основи : автореф. дис. на здобуття наук. ступеня канд. юрид. наук : спец. 12.00.09 «Кримінальний процес та криміналістика; судова експертиза; оперативно-розшукова діяльність» / О. І. Жеребко. - Запоріжжя, 2010. — 22 с.; Мосяженко В. Ю. Криміналістичне, судово-експертне забезпечення та оперативно-розшукове супроводження досудового розслідування злочинів у сфері суспільної моралі / В. Ю. Мосяженко // Наше право. — 2015. — № 2. - С. 109-116; Сегай М. Я. Судова експертологія - наука про судово-експертну діяльність / М. Я. Сегай // Вісн. Акад. прав. наук України. — 2003. - № 2(33)-3(34). - С. 740-762; Сопільник Р. Л. Експертне забезпечення правосуддя у контексті сучасних євроінтеграційних процесів в Україні / Р. Л. Сопільник // Криміналіст. вісн. - 2015. - № 1(23). - С. 39-44; Олійник $О$. О. Адміністративно-правове регулювання судово-експертної діяльності : монографія / О. О. Олійник, В. В. Галунько, О. М. Сщук. - Херсон : Грінь Д. С., 2015. - 224 с.; Пиріг I. В. Предмет і система судової експертології / І. В. Пиріг // Наук. вісн. Київ. нац. ун-ту внутр. справ. - 2010. - № 6. - С. 223-231; Він же. Судова експертологія: проблеми формування предмета та системи науки // Наук. вісн. Дніпропетр. держ. ун-ту внутр. справ. - 2013. - № 2. - С. 485-493; Федчииина $B$. B. Сутність державного управління у сфері експертного забезпечення правосуддя в Україні [Електронний ресурс] / В. В. Федчишина // Державне управління: 
науковців є беззаперечним, проте їх доробки не вирішили всіх проблемних питань. Зокрема, досі не вироблено єдиної позиції до термінології; питання експертного забезпечення кримінального провадження не розглядалося з точки зору комплексного, системного підходу; відсутній єдиний підхід до розкриття змісту експертного забезпечення кримінального провадження тощо.

З урахуванням зазначеного та з метою з'ясування сутності й змісту експертного забезпечення кримінального провадження вирішенню підлягає таке наукове завдання - за допомогою аналізу існуючих наукових поглядів і положень чинного законодавства України визначити сутність експертного забезпечення кримінального провадження.

Уважаємо доречним розпочати висвітлення сутності експертного забезпечення зі з'ясування семантико-етимологічного трактування терміна «забезпечення». Під ним прийнято розуміти діяльність, спрямовану на постачання чогось у достатній кількості; задоволення кого-, що-небудь у якихось потребах; надання кому-небудь достатніх матеріальних засобів до існування; створення надійних умов для здійснення чого-небудь; гарантування чогось; захист, охорону кого-, що-небудь від небезпеки ${ }^{1}$. Тобто забезпечення насамперед полягає у створенні умов, сприятливих для реалізації завдань, що ставляться перед певним видом діяльності. Стосовно кримінального провадження застосовуються такі різновиди забезпечення: організаційне, кадрове, матеріально-технічне, фінансове, інформаційне, криміналістичне, експертне тощо. Причому ці види забезпечення нерідко співвідносяться між собою як загальне й окреме. Експертне забезпечення кримінального провадження, на наш погляд, $є$ складовою експертного забезпечення правосуддя, оскільки експертне забезпечення здійснюється як у кримінальному, так і в адміністративному, цивільному, господарському процесах та під час виконавчого провадження. Як зазначає Ю. М. Чорноус, у контексті вирішення завдань криміналістичного забезпечення кримінального провадження техніко-криміналістичне й експертно-криміналістичне забезпечення, незалежно від тлумачення суті співвідношення цих термінів, $\epsilon$ його важливими складовими, що мають загальну мету: забезпечення діяльності з досудового розслідування, судового провадження науково-обгрунтованими засобами, методами та прийомами, а також криміналістичними рекомендаціями щодо їх практичного застосування ${ }^{2}$. У зв'язку з цим виникає запитання: чому автор уважає, що метою експертного забезпечення кримінального провадження $є$ розроблення тільки криміналістичних рекомендацій, адже експертне забезпечення стосується проведення не тільки криміналістичних

удосконалення та розвиток. - 2012. — № 12. - Режим доступу : http://www.dy.nayka. com.ua/?op=1\&z=660; Шерстюк B. М. Судово-експертна діяльність (організаційноправові та морально-етичні засади) : монографія / В. М. Шерстюк ; за ред. В. Ю. Шепітька. — Сімферополь : ДІАЙПІ, 2008. - 196 с.

1 Див.: Великий тлумачний словник сучасної української мови / уклад. і гол. ред. В. Т. Бусел. - К. : Ірпінь : ВТФ «Перун», 2009. - С. 375.

2 Див.: Чорноус Ю. М. Криміналістичне забезпечення кримінального провадження / Ю. М. Чорноус // Криміналіст. вісн. — 2014. — № 1(21). — С. 35. 
видів експертиз, а й інших: економічних, мистецтвознавчих, товарознавчих, будівельно-технічних, психологічних тощо.

Щодо сутності експертного забезпечення кримінального провадження, то в наукових колах відсутня одностайність стосовно як обрання термінології для позначення такої діяльності, так і трактування термінів. Так, у науковій літературі можна зустріти такі терміни: «судово-експертна діяльність», «експертне забезпечення правосуддя», «судово-експертне забезпечення правосуддя», «експертно-криміналістичне забезпечення» тощо. При цьому їх тлумачення також різняться.

Наприклад, В. В. Федчишина, досліджуючи сутність державного управління у сфері експертного забезпечення правосуддя в Україні, констатувала факт відсутності терміна «експертне забезпечення правосуддя» в системному аналізі наукових праць вітчизняних і зарубіжних дослідників та іншій літературі практичного спрямування. На думку вченої, по суті це формування й утвердження якісно нових принципів державного управління, визначених у преамбулі Закону України «Про судову експертизу» ${ }^{1}$, законодавчих норм щодо організації судово-експертної діяльності з метою забезпечення правосуддя України незалежною, кваліфікованою та об'єктивною експертизою, орієнтованою на максимальне використання досягнень науки й техніки ${ }^{2}$. Надалі у своїх наукових пошуках терміном «експертне забезпечення» оперує Р. Л. Сопільник. Висвітлюючи питання, пов'язані з експертним забезпеченням правосуддя в контексті сучасних євроінтеграційних процесів в Україні, він з'ясовує сутність, зміст і значення судово-експертної діяльності $^{3}$. В. Ю. Мосяженко, розглядаючи особливості досудового розслідування злочинів у сфері суспільної моралі, також використовує термін «судовоекспертне забезпечення». Зі змісту проведеного нею дослідження стає очевидним, що судово-експертне забезпечення ототожнюється 3 діяльністю судових експертів, спрямованою на організацію й проведення судових експертиз заради формування доказів, які відповідають вимогам Кримінального процесуального кодексу України ${ }^{4}$. Тобто науковці ототожнюють експертне забезпечення правосуддя та судово-експертну діяльність. На нашу думку, експертне забезпечення правосуддя здійснюється шляхом проведення судово-експертної діяльності, мета якої визначена в преамбулі Закону України «Про судову експертизу». Тому проаналізуємо наукові підходи до трактування терміна «судово-експертна діяльність».

На законодавчому рівні поняття судово-експертної діяльності вперше ввійшло у вжиток із прийняттям Закону України «Про судову експертизу». Цей нормативно-правовий акт тільки закріпив термін «судово-експертна діяльність» і їі мету - забезпечення правосуддя України незалежною, кваліфікованою та об'єктивною експертизою, орієнтованою на максимальне використання досягнень науки й техніки. Оскільки в цьому Законі містяться норми з науково-методичного, кадрового забезпечення судово-експертної

${ }^{1}$ Див.: Про судову експертизу : Закон України від 25.02.1994 № 4038-ХІІ // Відом. Верхов. Ради України. - 1994. - № 28. - Ст. 232.

2 Див.: Федчишина В. В. Указ. праця.

3 Див.: Сопільник Р. Л. Указ. праця.

4 Див.: Мосяженко В. Ю. Указ. праця. - С. 114-115. 
діяльності, то можна зробити висновок, що відповідно до сенсу Закону судово-експертна діяльність стосується не тільки проведення судових експертиз, а й спрямована на зазначені цілі. У 2013 р. на офіційному веб-сайті Міністерства юстиції України був оприлюднений проект Закону України «Про судово-експертну діяльність», у якому наводилося визначення судовоекспертної діяльності як особливого виду діяльності, пов'язаної з організацією та проведенням судових експертиз, експертних досліджень, спрямованих на забезпечення уповноважених осіб (органів), юридичних і фізичних осіб незалежними, кваліфікованими та об'єктивними висновками, орієнтованими на максимальне використання досягнень науки й техніки, створенням і вдосконаленням науково-методичної бази в галузі криміналістики та судової експертизи, а також державним управлінням у цій сфері ${ }^{1}$. Цей закон і досі залишається проектом, а отже законодавча регламентація судово-експертної діяльності на сьогодні відсутня.

М. Я. Сегай пропонує судово-експертну діяльність визначати як засновану на конституційних засадах діяльність органів державної влади, юридичних і фізичних осіб щодо забезпечення правосуддя незалежною, об'єктивною, кваліфікованою, такою, що спирається на досягнення науки та техніки, судовою експертизою ${ }^{2}$. На думку I. В. Пирога, змістом експертної діяльності є пізнання певних об'єктів, процесів або явищ спеціальними методами з метою отримання нової інформації про них ${ }^{3}$. О. I. Жеребко стверджує, що судово-експертна діяльність охоплює всю діяльність, пов'язану з проведенням судової експертизи, формуванням наукових основ нових видів і роду судових експертиз, організацією діяльності експертного підрозділу з проведення конкретних видів судових експертиз, підбором, підготовкою й навчанням кадрів для комплектування експертних підрозділів тощо. Більше того, як відмітну рису експертної діяльності вчений виділяє професіоналізацію, у зв'язку з якою цією діяльністю мають право займатися лише особи, котрі мають необхідні теоретичні знання та практичні навички, які пройшли спеціальну підготовку й займають відповідні посади або отримали процесуальні повноваження на проведення судової експертизи ${ }^{4}$. Аналіз наведених положень указує, що переважна більшість науковців акцентує увагу на тому, що судово-експертна діяльність насамперед виконує забезпечувальну функцію заради створення необхідних умов для проведення незалежної, об'єктивної, кваліфікованої, такої, що спирається на досягнення науки та техніки, судової експертизи. Тобто судово-експертна діяльність це не тільки діяльність з проведення судових експертиз. Із наведеною позицією ми погоджуємося. На нашу думку, головною функцією судовоекспертної діяльності є проведення обізнаними особами судових експертиз,

${ }^{1}$ Див.: 06.08.2013 Повідомлення про оприлюднення Закону України «Про судово-експертну діяльність» [Електронний ресурс] // М-во юстиції України : офіц. вебсайт. - Режим доступу : http://old.minjust.gov.ua/43603.

2 Див.: Сегай М. Я. Указ. праця. - С. 752.

3 Див.: Пиріг I. В. Предмет і система судової експертології. - С. 223-231; Biн же. Судова експертологія: проблеми формування предмета та системи науки. С. 485-493.

${ }^{4}$ Див.: Жеребко О. I. Указ. праця. - С. 5, 6, 16. 
а їі ядром є судова експертиза. Отже, поняття судово-експертної діяльності $є$ більш широким за змістом стосовно поняття судової експертизи. Відповідно не будуть повністю збігатися й коло суб'єктів судової експертизи (це виключно судові експерти) та коло суб'єктів судово-експертної діяльності (це, крім судових експертів, і керівник спеціалізованої установи, і судовоекспертна установа, як юридична особа, і відповідні підрозділи органів державної влади, до сфери управління яких входять спеціалізовані судовоекспертні установи). Експертне забезпечення правосуддя в кримінальному провадженні $є$ більш вузьким поняттям стосовно поняття експертного забезпечення правосуддя, яке включає в себе як забезпечувальну діяльність, так і діяльність із безпосереднього проведення судових експертиз їх суб'єктами. Тому вважаємо, що експертне забезпечення правосуддя та експертне забезпечення кримінального провадження співвідносяться як загальне й окреме, ціле й частина, а судово-експертна діяльність є рушійним механізмом експертного забезпечення правосуддя.

О. О. Олійник зі співавторами зазначають, що судово-експертна діяльність полягає в проведенні законної, незалежної, об'єктивної та повної судової експертизи на основі спеціальних знань матеріальних об'єктів, явищ і процесів, які містять інформацію про обставини юридичної справи, а також у діяльності публічної адміністрації стосовно: забезпечення умов праці судового експерта за місцезнаходженням об'єктів дослідження; створення судово-експертних спеціалізованих установ; забезпечення науково-методичної та організаційно-управлінської діяльності судово-експертних установ; забезпечення організаційно-правових засад діяльності Координаційної Ради з проблем судової експертизи; ведення Державного реєстру атестованих судових експертів; організаційно-правових засад діяльності експертнокваліфікаційної комісії; організаційно-правових засад здійснення навчання фахівців для спеціалізованих установ, які проводять судові експертизи; організаційно-правових засад атестації судових експертів тощо ${ }^{1}$. Із приводу наведеного зазначимо таке. Ці положення повною мірою передають зміст діяльності з експертного забезпечення правосуддя (судово-експертної діяльності), у тому числі й у кримінальному провадженні, однак через свою громіздкість ускладнюють їх сприйняття. Адже дефініція будь-якого явища чи процесу повинна бути лаконічною, а не просто містити перелік складових елементів, ознак, завдань, суб’єктів і методів реалізації.

Неможливо з'ясувати сутність експертного забезпечення кримінального провадження попередньо не 3'ясувавши сутність поняття кримінального провадження. Останнє, згідно з п. 10 ч. 1 ст. 3 Кримінального процесуального кодексу України, визначається як досудове розслідування і судове провадження, процесуальні дії у зв'язку із учиненням діяння, передбаченого законом України про кримінальну відповідальність. Відповідно сутність експертного забезпечення кримінального провадження полягає в налагодженні, організації та реалізації діяльності, спрямованої на створення сприятливих умов для виконання суб'єктами судово-експертної діяльності своїх професійних обов'язків, у тому числі в проведенні судових експертиз під час досудового розслідування й судового провадження, процесуальних дій

${ }^{1}$ Див.: Олійник О. О., Галунько В. В., Єщук О. М. Указ. праця. - С. 28. 
у зв'язку із вчиненням кримінально-караного діяння, з метою виконання завдання кримінального провадження.

Отже, експертне забезпечення кримінального провадження є багатоаспектною категорією. По-перше, воно є складовою експертного забезпечення правосуддя і тісно пов'язане з поняттям судово-експертної діяльності. По-друге, експертне забезпечення кримінального провадження є цілісною системою, яка включає в себе окремі структурні елементи, котрі перебувають у тісному взаємозв'язку між собою й об'єднані спільною метою. Тому під експертним забезпеченням кримінального провадження пропонуємо розуміти діяльність із створення умов для виконання суб'єктами судово-експертної діяльності своїх професійних обов'язків, у тому числі з проведення судових експертиз під час досудового розслідування та судового провадження, процесуальних дій у зв'язку із вчиненням кримінально-караного діяння, 3 метою реалізації завдання кримінального провадження.

\section{СУЩНОСТЬ ЭКСПЕРТНОГО ОБЕСПЕЧЕНИЯ УГОЛОВНОГО ПРОИЗВОДСТВА}

\section{Ткаченко Н. Н.}

Акиентировано внимание на отсутствии согласованного мнения об используемой терминологии для обозначения деятельности по экспертному обеспечению правосудия. Раскрыто содержание понятий «обеспечение», «экспертное обеспечение правосудия», «судебно-экспертная деятельность» и др. Проанализировано состояние нормативно-правовой регламентащии понятия «судебно-экспертная деятельность». Предложено рассматривать экспертное обеспечение уголовного производства как структурный элемент экспертного обеспечения правосудия. Приведена авторская трактовка понятия «экспертное обеспечение уголовного производства».

Ключевые слова: экспертное обеспечение, судебно-экспертная деятельность, уголовное производство, судебная экспертиза.

\section{ESSENCE OF THE EXPERT PROVISION OF CRIMINAL PROCEEDINGS}

\section{Tkachenko N. M.}

In paper attention is accented on the lack of agreed opinions about the used terminology to describe activity on the expert provision of justice. The content of notions "provision», "expert provision of justice», "forensic and expert activity» and others are disclosed. The state of normative legal regulation of the notion "judicial and expert activity» is analyzed. Unfortunately, as of today the legislative regulation of forensic and expert activity is absent. Only the draft Law of Ukraine "On forensic and expert activity" provides its definition as a special kind of activity related to the organization and carrying out forensic examinations, expert researches aimed at ensuring authorized persons (bodies), legal entities and individuals with independent qualified and objective conclusions oriented at maximum use of science and techniques achievements, creation and improvement of scientific and methodological basis in the field of criminalistics and forensic examination, as well as the state administration in this area. It's proposed to consider expert provision of the criminal proceedings as a structural element of the expert provision of justice. Expert provision of criminal proceedings is a multidimensional category. Firstly, it is a component 
of expert provision of justice and is closely related to the notion of forensic and expert activity. Secondly, expert provision of criminal proceedings is holistic system which includes separate structural elements which are in close relationship between themselves and united by a common purpose. Therefore, under expert provision of criminal proceeding it's proposed to understand the activity to create conditions for fulfillment of professional duties by the subjects of forensic and expert activity including carrying out forensic examinations during pre-trial investigation and judicial proceedings, procedural actions in connection with a punishable offense with the purpose of criminal proceedings tasks.

Keywords: expert provision, forensic and expert activity, criminal proceedings, forensic examination.

УДК 343.98

Е. Б. Сімакова-Сфремян, заступник директора з наукової роботи Харківського НДІСЕ, кандидат юридичних наук, старший науковий співробітник

\section{ІНТЕГРАЦІЙНІ ПРОЦЕСИ В СУДОВІЙ ЕКСПЕРТИЗІ: СУТНІСТЬ ТА ПРОБЛЕМНІ ПИТАННЯ КОМПЛЕКСНИХ ДОСЛІДЖЕНЬ}

Сучасна наука розглядає комплексність досліджень як одну із закономірностей прочесу пізнання. Судова експертиза, яка з метою вирішення завдань судочинства спрямована на використання знань, накопичених у різних галузях науки, у процесі науково-технічного прогресу постійно отримує вплив інтеграційних процесів, щуо відбуваються в ичих галузях. Наукові публікації свідчать про те, щзо інтеграція знань у судовій експертизі-цуе закономірний процес ї̈ розвитку, один із головних важелів впливу на формування засад комплексних судово-експертних досліджень; нині вона набуває все більшого поглиблення й поширення. Вивчаючи форми комплексирування в судовій експертизі, необхідно виходити з аналізу предмета, завдань, об'єктів, суб'єктів $і$ методик комплексних досліджень, оскільки інтеграчійні процеси реалізуються в розвитку судової експертизи за предметом інтеграції знань, завданнями судової експертизи, об'єктами, суб'єктами інтеграчї знань та методами.

Ключові слова: судова експертиза, інтеграційні процеси, комплексні експертні дослідження, комплексна експертиза, комплекс досліджень, методика, метод.

Термін «інтеграція» (від лат. integratio - відновлення, заповнення) означає об'єднання в ціле будь-яких частин, процес розвитку, пов'язаний із об'єднанням у ціле раніше різнорідних частин та елементів ${ }^{1}$. Це поняття застосовується в багатьох науках, практичній діяльності та затвердилося в ста-

1 Див., напр.: Словник іншомовних слів / за ред. О. С. Мельничука. - 2-ге вид., випр. і допов. - К. : УРЕ, 1985. - 966 с.; Философский энциклопедический словарь / редкол.: С. С. Аверинцев, Э. А. Араб-Оглы, Л. Ф. Ильичев и др. - 2-е изд. - М. : Сов. энциклопедия, 1989. - 815 с. 